Felicity Meakins and Rachel Nordlinger

A Grammar of Bilinarra 


\section{Pacific Linguistics}

Managing editor

Paul Sidwell

Editorial board members

Wayan Arka

Mark Donohue

Bethwyn Evans

Nicholas Evans

Gwendolyn Hyslop

David Nash

Bill Palmer

Jane Simpson

Andrew Pawley

Malcolm Ross 
Felicity Meakins

Rachel Nordlinger

\section{A Grammar of Bilinarra}

An Australian Aboriginal Language of the Northern Territory 
ISBN 978-1-61451-268-4

e-ISBN 978-1-61451-274-5

ISSN 1448-8310

\section{Library of Congress Cataloging-in-Publication Data}

A CIP catalog record for this book has been applied for at the Library of Congress.

Bibliographic information published by the Deutsche Nationalbibliothek

The Deutsche Nationalbibliothek lists this publication in the Deutsche Nationalbibliografie; detailed bibliographic data are available in the Internet at http://dnb.dnb.de.

(C) 2014 Walter de Gruyter, Inc., Boston/Berlin

(C) 2014 Bilinarra sound files and recordings Bilinarra people Typesetting: RoyalStandard, Hong Kong

Printing and binding: Hubert \& Co. GmbH \& Co. KG, Göttingen

(2) Printed on acid-free paper

Printed in Germany

www.degruyter.com 